\author{
Marxan을 이용한 도시하천의 \\ 보전지역 설정 및 생태적 관리방안 연구 ${ }^{\dagger}$ \\ - 서울시 중랑천을 대상으로 - \\ 윤호근 ${ }^{*}$ 한봉호 ${ }^{* *}$ - 곽정인 ${ }^{* * *}$ \\ "국립수목원 DMZ자생식물연구과 석사연구원 · "서울시립대학교 조경학과 교수·" (재)환경생태연구재단 연구원

\section{A Study on Zoning and Management of Conservation Area and Ecological Management Plan on Urban Stream Using Marxan - A Case of Jungrangcheon(Stream) in Seoul -} \\ Yun, Ho-Geun ${ }^{*} \cdot$ Han, Bong-Ho ${ }^{* *} \cdot$ Kwak, Jeong-In ${ }^{* * *}$ \\ "Post-Master Researcher, DMZ Botanic Garden, Korea National Arboretum \\ "* Professor, Dept. of Landscape Architecture, University of Seoul \\ ${ }^{* * * *}$ Researcher, Environment Ecosystem Research Foundation
}

\begin{abstract}
This study presented a plan for the establishment of conservation areas and the ecological management of those areas in the stream based on the Marxan with Zones Program for a Jungrangcheon Stream in downtown Seoul. The application of the Marxan with Zones Program included the stage of planning unit setting, application of mapping indices, numerical correction for repetitive analysis, creation of scenario-specific optimizations through analysis, analysis of sensitivity by scenario, review, and the selection of optimal plans among the scenarios considered. As a result of the establishment of a conservation area near Jungrangcheon Stream, which has several watershed areas, including an upper-middle-class wildlife protection zone, which was previously designated and managed as a conservation area, and the migratory protection zone downstream of Jungrangcheon Stream were designated as key conservation areas. A number of wild birds were observed in the upper reaches of Jungrangcheon Stream, adjacent to the forests of Suraksan Mountain and Dobongsan Mountain. The downstream area is a habitat for migratory birds that travel along the stream and the adjacent river ecosystem, including the Hangang River confluence and Cheonggyecheon Stream confluence. Therefore, the upper and lower reaches of Jungrangcheon Stream are connected to forest ecosystems such as Dobongsan Mountain, Suraksan Mountain, and Eungbongsan Mountain, as well as urban green area and river ecosystems in the basin area, which influence the establishment of conservation areas. This study verified the establishment and evaluation of existing conservation areas through the Marxan with Zones Program during the verification of the conservation areas and was presented as in-stream management and basin management method to manage the basin areas derived from core conservation areas determined through the program.
\end{abstract}

\footnotetext{
${ }^{+}$: 본 논문은 윤호근의 석사학위논문(2018) 일부를 보완 발전시킨 것임.

Corresponding author: Jeong-In Kwark, Researcher, Environment Ecosystem Research Foundation, Seoul 05643, Korea, Tel.: +82-2412-1242, E-mail: kkwark@uos.ac.kr
} 


\section{Key Words: Hydrophilic Function, Watershed, Impermeable Index, Biotope Index, UNESCO MAB}

\section{국문초록}

본 연구는 서울시 도심 하천 중 국가하천인 중랑천을 대상으로 보전지역 설정 프로그램인 Marxan with zones 프로그램 을 기반으로 한 하천 내 보전지역 설정 및 생태적 관리방안을 제시하였다. Marxan with zones 프로그램 적용은 유역권 (planning unit) 설정, 맵핑지표(mapping index) 적용, 반복적인 분석을 위한 수치보정, 분석을 통한 시나리오 별 최적안 작성, 시나리오 별 민감도 분석, 시나리오 중 최적안 검토 및 선정 단계로 진행하였다. 중랑천 내 보전지역 설정 결과, 기존에 보전지역으로 지정 및 관리하고 있는 중랑천 상류 야생생물보호구역을 포함한 다수의 유역권과 중랑천 하류의 철새보호구역을 포함한 유역권이 핵심보전지역으로 설정되었다. 상류는 중랑천을 중심으로 수락산과 도봉산 등 산림이 인접하여 다수의 야생조류가 관찰되었다. 하류는 한강 합수부, 청계천 합수부 등 하천생태계가 인접하여 하천을 따라 이동하는 철새 도래지이다. 따라서 중랑천 상류와 하류는 유역권 내 도봉산, 수락산, 응봉산 등 산림생태계, 도심 내 녹지, 청계천 합수부, 한강 합수부 등 다양한 생태계와 연결되어 있어 보전지역 설정에 영향을 주었다. 본 연구는 보전지역 검증 시 Marxan with zones 프로그램을 통한 기존 보전지역 설정 및 평가를 검증하였고, 프로그램을 통해 핵심보전지역으로 도출된 유역권을 생태적으로 관리하기 위해 하천 내 관리방안과 유역권 관리방안으로 구분하여 제시하였다.

주제어: 친수기능, 유역권, 불투수지수, 비오톱지수, UNESCO $M A B$

\section{I. 서론}

1990년대 중반 이후 자연형 하천을 표방한 하천 정비 사업이 대도시를 중심으로 추진되면서 서울시의 중랑천, 우이천, 홍제 천, 탄천, 정릉천, 양재천, 수원시의 수원천 등이 최초로 정비가 실시되었다. 그러나 이런 사업들은 자연형 하천 조성을 목적으 로 보고 있지만, 생물서식처의 보전, 복원, 창조가 아닌 자전거 도로, 체육시설, 쉼터 등 시설의 이용에 초점을 둔 친수기능의 하천조성을 목표로 하고 있었다(Jung, 2010). 친수기능은 하천 의 생물서식처 기능이 충족되고 회복이 이루어진다면 자연스 럽게 수반되는 기능이므로 생물서식처 회복 이후에 고려되어 야 할 것이다(Woo, 2004).

따라서 하천정비 시 보전지역 평가 및 구간 별 관리평가가 필요하고, 생물다양성 증진 및 경관개선을 위해 인공화 된 하 천을 자연스러운 하천으로 복원하는 과정에서도 각 하천이 처 한 상황에 대한 진단수단으로서 하천 생물현황 평가 및 보전지 표 설정이 필요하였다. 현재 하천을 평가하는 기준은 하천 내 수질에 편중되어 있고, 생물서식처 분포 및 기능을 고려하지 않았으므로 수질의 개선만으로는 생태적 복원의 효과를 달성 하기 어렵다(Otto et al., 2004).

서울시는 2000년대 이후 도시개발로 인해 훼손된 하천의 물 리적 형태 및 생태적 기능의 복원을 목표로 서울시 내 19 개 하 천을 정비하는 생태하천 복원사업을 진행하였다. 생태하천 복 원사업은 생태적 기능 향상을 목적으로 하는 사업이 아닌 친수 기능의 확장을 통한 하천 내 이용자 증대를 목표로 자전거도로,
운동시설, 산책로 조성, 쉼터 조성 등이 먼저 진행되었다(Seoul, 2017). 진정한 생태하천 복원사업을 위해서는 하천 구간 별 모 니터링을 통한 과학적 조사 및 평가를 기준으로 생물종 출현현 황 및 서식범위를 확인하여 도면화를 실시하고, 생태적으로 우 수하다고 판단되는 지역에 대한 핵심보전지역 선정 및 관리방 안 수립 등 전략설정이 필요하였다.

하지만 대부분 하천의 보전과 관리는 하천구역 내로 한정되 어 있어 주변 도시지역에서 미치는 영향과 생태적 연결성 등의 과제를 해결하는 데 한계가 있으며, 하천의 모니터링 및 생태 적 가치 평가 또한 생물상에 주로 편중되어 있다. 또한 관리 목 적에 따른 보전지역 및 완충지역 등의 관리범위 설정에 있어 정량적으로 도출된 공간적 범위를 바탕으로 구분하는데 한계 를 갖고 있다. 따라서 하천에 영향을 미치는 유역권 차원에서의 관리구역 설정과 하천과 유역권의 생태적 가치를 종합적으로 해석하고, 정량적인 공간단위의 의사결정과정을 거쳐 합리적인 생태적 복원과 지속가능한 관리를 위한 접근이 필요하였다.

Marxan with zones는 다양한 용도지역 설정이 가능한 Marxan 프로그램의 확장판으로 데이터 유형에 따라 작성된 도면을 중 첩하고 설정된 보전지역간 연결수치 조정(BLM)과 수치보정 (FPF) 등 변수 부여를 바탕으로 $1,000 ~ 1,000,000$ 회 이상을 반 복하는 오차보정 작업(simulated annealing)을 통해 보전지역 간 연결성을 고려한 시나리오를 도출하여 최종안 설정을 쉽게 할 수 있다(Watts et al., 2009). 도출된 최종안은 대규모 보전 계획 문제를 반복적이고 적정화된 알고리즘을 통해 해결안을 제시해 주며, 유역권 간 네트워크 연결성을 고려하여 최대한 
넓은 면적의 보전지역을 설정해 주어 생물 서식처 조성과 경제 적으로도 우수한 지역을 찾아 줄 수 있다(Bos, 1993). Marxan 은 프로그램의 정량적인 분석과정을 거쳐 결과를 도출할 수 있 어 기존의 보호지역이나 관리범위 설정에 있어 발생할 수 있는 의사결정을 보다 합리적으로 진행할 수 있을 것으로 판단되었다.

본 연구는 하천의 형성과 유지에 영향을 미치는 유역권을 계 획 단위 설정하고, 기존의 생물상보다는 생태적 가치와 범위를 공간적으로 해석한 맵핑자료(Biotope map) 작성, Marxan 프 로그램을 이용하여 합리적이고 정량적인 의사결정과정을 통해 보전과 관리를 위한 구역의 설정과 관리방안 도출을 목표로 하 였다. 서울시 내 생태하천 복원사업이 조성된 하천 중 규모가 크고 한강 지천 중 유일하게 국가 하천으로 지정되어 있는 중 랑천을 대상으로 용도지역 설정현황 및 보전지역 설정 적절성 을 검토하였고, 중랑천의 전체적인 관리방안을 제안하였다.

\section{II. 연구방법}

\section{1. 연구대상지 선정}

본 연구의 대상지는 서울시 내 흐르는 30 개 하천 중 하천의 유형, 규모, 하천 상류와의 연계 여부, 하천 하안구조 및 특성, 보호지역 지정 관리 등을 검토하여 국가하천인 중랑천을 대상 으로 하였다. 중랑천은 대규모의 여러 지자체에 걸쳐 있는 광 역형 하천으로 서울시 한강의 지천 중 유일하게 국가하천으로 지정되어 있으며, 둔치가 발달된 구조이었다. 중랑천은 하천의 규모가 크며, 하류와 상류구간에 다양한 야생조류 및 표범장지 뱀을 보호하기 위한 야생동물보호구역으로 지정되어 있는 등 생태적 가치가 높은 하천이나, 이용 중심의 조성과 관리가 지 속적으로 진행되어 왔고, 하천 주변이 대부분 고밀도 도시로 개발되면서 유역권 제내지의 영향을 많이 받게 되어 연구대상 지로 선정하였다.

중랑천은 한강합수부에서 의정부 서울시 경계까지 하천연 장 $24 \mathrm{~km}$ 구간으로 이루어져 있었다. 중랑천 상류는 도봉산, 수 락산 등 산림생태계와 서울 창포원 내 습지, 중랑천 상류 야생 생물보호구역 등 하천 주변으로 다양한 유형의 생물서식공간 이 인접하고 있었다. 중랑천 중류는 초안산, 영축산 등 산림과 방학천 합수부, 우이천 합수부, 묵동천 합수부 등 하천 합수부 와 연결되는 곳으로 타 하천을 통한 식물 및 동물의 이동가능 성이 있었다. 중랑천 하류는 한강 합수부, 청계천 합수부, 철새 보호구역, 서울 숲 등 산림생태계, 하천 합수부, 도심 내 녹지 등 다양한 유형의 생물서식처와 연결되어 있었다.

\section{Marxan 프로그램을 활용한 보전지역 실행 체계}

생태적 가치, 사회 - 문화적 가치를 반영한 지구 구분은 Marxan with zones(v. 2.01)프로그램을 활용하였으며, 보전지역 맵핑 결과 검증에서 최종안 선정은 Marxan with zones 프로그램을 통해 도출된 시나리오에 대한 적합성을 검토하여 판단하였다. 각 시나리오 별 최종안을 선정 후 각 단계별로 적합성을 재검 토하였다. 1단계는 보전지역간 인접 여부, 2단계 유역권 내 핵 심보전지역과 완충지역의 비율, 3 단계 보전지역 설정 시 비오 톱의 반영 여부, 4 단계 보전지역 설정의 적절성 여부 등을 고려 하여 최종안을 선정하였다(Figure 1 참조).

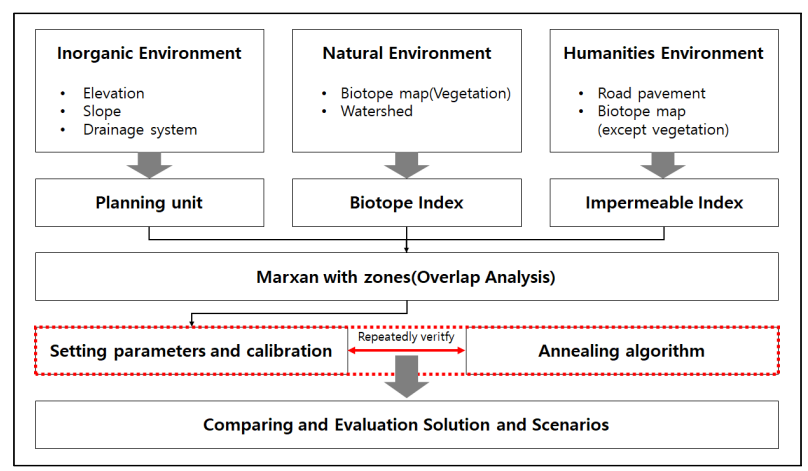

Figure 1. Marxan with zones system programing algorithm

\section{3. 조사·분석 방법}

\section{1) 유역권 분석}

유역권 분석은 하천의 친환경적인 보전 및 관리를 위해 생물 서식처 범위설정 및 이동범위를 고려하여 유역권 범위를 설정 하였다. 유역권 분석을 위한 수계의 구분은 Horton(1945)과 Strahler(1952)의 방법을 이용하였으며, 국토교통부에서 제공 하는 서울시 $1 / 1,000$ 수치지형도를 이용하여 Arcgis 10.3 프로 그램으로 분석하였다. 유역권 규모는 표준유역보다 작은 세유 역권을 단위 유역권 기준으로 하였고, 유역권의 평균 크기는 중규모 야생동물 핵심 행동권을 단위 유역권 선정기준에 따라 설정하였으며, 선정된 수치는 중형 포유류인 너구리, 삵, 오소리 (Lee et al., 2014)를 기준으로 하여 유역권 크기를 조정하였다.

2) 맵핑지표 산정

\section{(1) 불투수지수}

불투수지수는 서울시 도시생태현황지도을 활용하여 유역권 내 건폐지와 불투수포장지 등 개발지역을 포함하는 불투수포 장비율을 활용하여 분석하였다. 불투수포장비율은 경사와 수계 를 기준으로 작성된 대상지 별 유역권 경계와 서울시에서 제공 하는 서울시 도시생태현황도(Seoul, 2015)를 Arcgis 10.3 프로 그램 내 Clip 기능을 이용하여 유역권 경계 별 불투수포장비율 현황을 분석하였다.

불투수포장비율을 $10 \%$ 미만은 1 등급, $10 \%$ 이상 $30 \%$ 미만 
은 2 등급, $30 \%$ 이상 $50 \%$ 미만은 3 등급, $50 \%$ 이상 $70 \%$ 미 만은 4 등급, $70 \%$ 이상은 5 등급으로 구분하여 등급 별 면적을 산출하였다. 불투수지수는 유역권 별 작성된 등급 별 면적에 가중치를 곱하여 값을 산출하였다. 가중치는 1 등급 $1.0,2$ 등급 $0.75,3$ 등급 $0.5,4$ 등급 $0.25,5$ 등급 0 등 5 개의 등구간으로 구분 하여 설정하였다. 불투수지수는 1 개 유역권에서 작성된 폴리곤 면적과 가중치를 곱하여 가중치 면적을 산출하고, 유역권을 기 준으로 산출값을 모두 더한 후 유역권 전체면적으로 나누어서 유역권 내 불투수지수를 도출하였다. 도출된 불투수지수의 값 은 높을수록 산림 및 녹지와 인접하여 생물서식처에 유리하였 으나, Marxan with zones 프로그램은 지수화된 수치가 낮을수 록 보전가치가 높게 평가되므로 지수의 최대값인 1 에서 등급 별 면적을 통해 산출된 불투수지수를 차감하여 역 불투수지수 로 변경한 후 프로그램에 적용하였다.

\section{(2) 비오톱지수}

비오톱지수는 $1 / 1,000$ 수치지형도를 활용하여 현장조사를 통 해 하천 내 식생 분포지역 및 시설물 조성지역 등을 구분하고, 식생분포지역에 대해 우점종을 중심으로 한 식생상관에 따라 현존식생도를 작성하였다. 이를 토대로 식생의 자연성, 생육특 성 및 피복도 등을 기준으로 비오톱 유형화하였고, 서울시 도 시생태현황지도 비오톱 유형평가기준을 활용하여 5 개 등급으 로 평가하였다. 하천을 제외한 유역권 전체의 비오톱 평가자료 는 서울시 도시생태현황지도에서 추출하였다.

비오톱지수는 Choi(2008)의 방법을 응용하여 유역권에 포함 된 하천 구간별, 하천을 제외한 유역권별로 각각의 평가등급에 따른 폴리곤 면적에 가중치를 곱하여 등급별 가중치 면적을 산 출하였고, 산출된 값을 모두 더한 후 각각의 총 면적으로 나누 어 비오톱지수를 산출하였다. 유역권별 최종 비오톱지수는 하 천의 비오톱지수와 하천을 제외한 유역권 비오톱지수의 평균 값으로 산출하였다. 가중치는 불투수지수와 동일하게 적용하였 다. 도출된 비오톱지수는 높은 값이 생태적으로 우수하고 생물 서식처에 유리한 것을 의미하나, Marxan with zones 프로그램 은 지수화된 수치가 낮을수록 보전가치가 높게 평가되므로 지수 의 최대값인 1 에서 등급 별 면적을 통해 산출된 비오톱지수를 차감하여 역 비오톱지수로 변경한 후 프로그램에 적용하였다.

\section{3) Marxan with zone을 활용한 시나리오 분석}

Marxan with zone프로그램에서는 최종안의 반복횟수와 도 출되는 최종안의 개수, 수치보정 계수인 $\mathrm{FPF}$ 와 지구간 연결 수치를 설정하는 Zoneboundcost 등 수치보정을 해야 한다. 반 복횟수를 통한 수치보정은 반복횟수와 수치감소 단위를 조정하 여 목적기능값(score)을 도출하는 작업으로 Marxan with zones 분석을 통한 최종값인 목적기능값(score)은 계획단위(planning unit)에 반영된 비용, 계획단위의 외곽 길이비용, 특성지표 (feature)가 반영되지 않았을 경우 Penalty 비용 등 세 가지 수 치의 합으로 구성된다. 목적기능값이 낮을수록 가장 효율적인 해결안을 도출할 수 있으며, 목적기능값의 오류를 최소화하고 실효성 있는 값을 도출하기 위해 수치보정 단계가 필수적이다 (Watts et al., 2008).

수치보정은 보전지역 설정 시 단위와 자릿수가 다른 다수의 지표들이 반영되는 한계를 정하기 위해 기본적인 가이드라인 을 설정하는 단계이다. Marxan with zones 적용을 위한 사용자 가이드(Watts et al., 2008)에서는 해결안(Solution)의 반복횟 수, 도출하는 해결안의 개수 수치보정 계수인 $\mathrm{FPF}$ 와 지구간 연결수치를 위미하는 Zoneboundcost 값 등 4가지에 대한 수치 보정을 강조하고 있다. 수치보정단계로 제시되지 않지만 발생 비용 중 상대적으로 수치가 큰 계획단위의 외곽경계의 길이 (boundary length)에 대한 보정을 위해 유역권과 비교해 가며 $\mathrm{BLM}$ 수치를 맞추어가는 것이 필요하다고 하였다(Andron et al., 2010). 수치보정 중 도출되는 해결안의 개수는 결과에 큰 영향을 주지않으므로 초기 설정값인 10회로 고정하였다(Watts et al., 2008).

$\mathrm{BLM}$ 과 $\mathrm{FPF}$ 는 계수로 연구자가 지표의 수치를 확인하면서 보정할 수 있도록 되어 있고, 담금질 알고리즘(annealing)을 반 영하여 반복횟수와 수치감소 단위를 설정한다. BLM, FPF, Zoneboundcost를 수치보정하는 방법으로는 Marxan with zones 적용을 위한 사용자가이드(Watts et al., 2008)에서 제시하는 방법으로 0.00001 부터 10 단위로 숫자를 증가하면서 가장 적합 한 수치를 찾는 과정이었다.

\section{III. 결과 및 고찰}

\section{1. 유역권 설정(Planning Unit)}

중랑천 유역권은 총 27 개로 설정되었고, 유역권 전체 면적은 $58,746,161 \mathrm{~m}^{2}$ 이었다. 유역권 내 주요 수계로는 유역권 중앙을 흐르는 중랑천과 중랑천 상류의 유역권에서 방학천, 무수천 등 이 연결되어 있었다. 중류에서는 우이천, 묵동천, 면목천 등이 연결되어 있었고, 하류에서는 전농천, 청계천, 한강합수부 등이 연결되어 있었다. 유역권과 인접한 주요 지점으로는 도심 내 녹지시설을 조성한 서울창포원. 서울숲 등 공원녹지시설, 도봉 산, 수락산, 초안산, 개운산, 응봉산 등 중랑천과 인접하는 산림 생태계, 한강, 청계천, 우이천, 묵동천 등 하천생태계, 녹천교상계교 구간에서 서식하는 표범장지뱀을 보호하기 위해 지정 된 중랑천 야생생물보호구역 등이 위치하고 있었다.

중랑천 유역권 내 가장 넓은 면적을 차지하는 곳은 중랑천 중류에 위치하는 16 번 유역권으로 유역권 전체면적의 $9.3 \%$ 를 차지하였다. 중랑천 유역권 16 번은 대단위 주거시설지 및 상업 
시설지가 밀집하는 지역으로 다수의 시설지가 분포하고 있었 으나, 유역권 주변으로 초안산, 영축산 등 산림생태계와, 당현 천 등 하천생태계가 위치하는 곳으로 녹지 및 오픈스페이스 면 적이 넓게 분포하는 지역이었다. 다음으로 넓은 면적을 차지하 는 유역권 15 번은 유역권 16 번과 인접하는 유역권으로 중랑천 수계를 중심으로 대단위 주거시설 및 상업시설지가 밀집하고 있는 지역이었다. 세 번째로 넓은 면적을 차지하는 유역권 25 번은 중랑천 상류에 위치하는 곳으로 하천을 중심으로 고밀도 시가화지역이 분포하는 지역이었으나, 방학천 등 하천 생태계 와 멸종위기종을 보호하는 야생생물보호구역이 위치하였다.

중랑천 내 설정된 유역권이 야생동물의 서식 면적의 소규모 야생생물 서식범위인 $1 \mathrm{~km}^{2}$ 보다 큰 이유는 도봉산, 수락산, 개 운산, 응봉산 등 경사의 범위가 큰 산림생태계와 방학천, 우이 천, 묵동천, 청계천 등 경사의 차이가 없는 도시 하천생태계가 인접하기 때문에 경사 및 수계를 기준으로 설정되므로 유역권 의 면적이 넓게 도출되었다(Figure 2 참조).

\section{2. 맵핑 지표}

1) 불투수지수(Impermeable index)

불투수지수는 높을수록 물순환기능과 자연성이 우수하였고, 낮을수록 포장지 및 시가지의 비율이 높아 자연성이 낮은 것을 의미한다. 중랑천 내 불투수포장비율을 이용한 불투수지수 산 출 결과, 중랑천 상류의 유역권 27 번이 불투수지수 0.87 로 나타

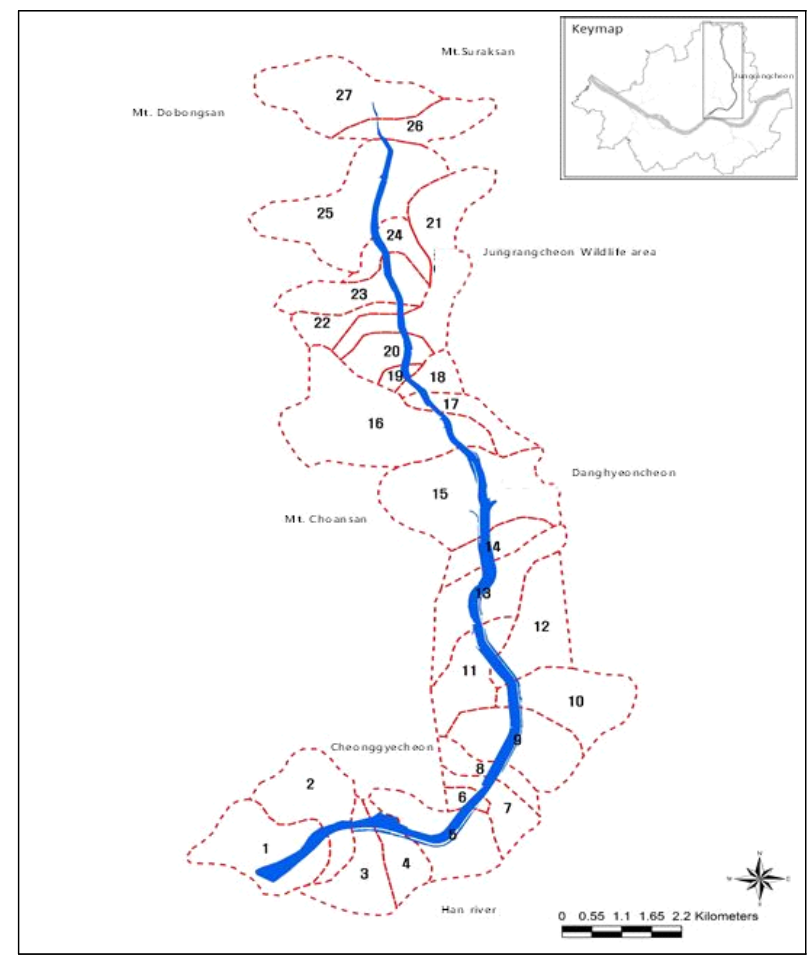

Figure 2. Jungrangcheon stream watershed
나 전체 유역권 중 1 순위이었다. 유역권 27번은 중랑천 유역권 내 도봉산, 수락산 등 산림생태계가 인접하였고, 서울습지원 등 근린공원 내 녹지가 인접하여 산림생태계, 하천생태계가 연결 될 수 있는 공간이었다. 또한 하천 내 주거지, 상업지 등 시가 화시설이 적어 보전지역 설정 시 하천 주변지역까지 확대가 가 능하다고 판단되었다. 두 번째로 불투수지수가 높은 곳은 유역 권 26 번으로 불투수지수가 0.71 , 전체 유역권 중 2순위이었다. 유역권 26번은 유역권 27번과 같은 중랑천 상류에 위치하는 곳 으로 도봉산, 수락산 등 산림생태계가 인접하고, 도봉천 합수부 등 산림과 하천 생태계가 연결되는 곳이었다. 중랑천 상류의 유역권 26번과 27번은 하나의 유역권으로 보전 및 관리계획을 설정하여 생물 서식처 보전 및 이동통로 조성, 주변 산림과 연 계되는 네트워크 녹지 조성 등이 필요하다고 판단되었다.

세 번째는 중랑천 중류에 위치하는 유역권 19,20 번이었다. 유역권 19,20 번은 불투수지수가 $0.60,0.50$ 으로 전체 유역권 중 3,4 순위를 차지하였다. 중랑천 중류에 위치한 유역권 19,20 번 은 당현천, 방학천 합수부 등 하천생태계와 초안산, 영축산 등 산림생태계가 인접하고 있었다. 중랑천 중류는 하천 주변의 산 림, 하천을 연결하는 서식처 및 이동통로 역할을 하므로 보전 할 가치가 있었다. 유역권 주변으로 불암산, 오패산, 북서울 꿈 의 숲 등 산림생태계 축이 연결될 가능성이 있는 지역으로 판 단되었다. 네번째로 유역권 1,3 번은 유역권 전체 6,7 순위를 차 지하며, 중랑천 합수부, 청계천 합수부와 인접하는 곳이었다. 또한 유역권 내 철새보호구역이 위치하여 한강합수부, 중랑천 구간에 다수의 야생조류가 관찰되는 지역이었다.

중랑천 하류의 유역권 1,3 번은 남산과 인접하는 응봉산과 대현산 근린공원, 서울숲 등 근린공원, 응봉체육공원, 살곶이 체육공원 등 친수기능을 가지는 공원 · 녹지 등 다양한 유형의 공원 - 녹지 뿐만 아니라, 남산 매봉산 응봉산으로 연결된 산 림생태축, 청계천 합수부, 한강합수부 등 하천 생태계를 모두 보유하는 곳으로 생물다양성이 풍부한 지역이었다. 따라서 다 양한 유형의 생태계를 보전하기 위해 구간 별 보전강도를 차별 화한 보전방안이 필요하다 판단되었다.

중랑천 유역권 내 불투수지수가 가장 낮은 곳은 중랑천 하류 의 유역권 $6,7,8$ 번 지역으로 불투수지수가 $0.13,0.13,0.17$ 로 나타났고, 전체유역권 중 $24,25,27$ 순위를 차지하고 있었다. 중랑천 하류의 유역권 $6,7,8$ 번은 군자역과 장한평역 구간에 위치하는 곳으로 고밀도 시가지가 인접하여 포장지의 비율이 높고, 식생분포지역의 비율이 낮아 생물의 서식과 자연적인 물 순환에 어려움이 있었다. 또한 하천 내 조성된 체육공원으로 인해 불투수포장비율이 높아져 보전지역 설정에 영향을 미쳤 다. 따라서 유역권 내 보전지역 설정 시 중랑천 상류의 유역권 26,27 번과 중랑천 중류의 유역권 19,20 번, 중랑천 하류의 유역 권 1,3 번 등은 생물서식에 적합한 지역이었으며, 보전지역 설 정 시 우선적으로 반영해야 할 것이다(Table 1 참조). 
Table 1. Impermeable index by Jungrangcheon watershed

\begin{tabular}{|c|c|c|c|c|c|}
\hline \multicolumn{2}{|c|}{ Watershed } & $\operatorname{Area}\left(\mathrm{m}^{2}\right)$ & $\begin{array}{c}\text { Conversion } \\
\text { area }\left(\mathrm{m}^{2}\right)\end{array}$ & $\begin{array}{l}\text { Urbanization } \\
\text { index }\end{array}$ & Priority \\
\hline \multirow{27}{*}{$\begin{array}{c}\text { Jungrang } \\
\text { Cheon } \\
\text { Stream }\end{array}$} & 1 & $5,484,821$ & $2,344,903$ & 0.43 & 7 \\
\hline & 2 & $4,281,807$ & $1,019,616$ & 0.24 & 14 \\
\hline & 3 & $4,060,263$ & $1,824,444$ & 0.45 & 6 \\
\hline & 4 & $2,567,248$ & 521,888 & 0.20 & 17 \\
\hline & 5 & $4,216,688$ & 866,034 & 0.21 & 16 \\
\hline & 6 & $1,122,063$ & 143,641 & 0.13 & 24 \\
\hline & 7 & $3,311,945$ & 436,948 & 0.13 & 25 \\
\hline & 8 & $2,474,912$ & 187,955 & 0.08 & 27 \\
\hline & 9 & $4,415,335$ & 732,454 & 0.17 & 19 \\
\hline & 10 & $3,708,743$ & $1,812,183$ & 0.49 & 5 \\
\hline & 11 & $3,103,306$ & 821,731 & 0.26 & 13 \\
\hline & 12 & $4,082,394$ & 507,774 & 0.12 & 26 \\
\hline & 13 & $5,833,921$ & $1,255,203$ & 0.22 & 15 \\
\hline & 14 & $2,870,166$ & 558,146 & 0.19 & 18 \\
\hline & 15 & $6,911,134$ & $1,045,017$ & 0.15 & 20 \\
\hline & 16 & $8,039,576$ & 2,923,332 & 0.36 & 10 \\
\hline & 17 & $2,310,112$ & 672,913 & 0.29 & 12 \\
\hline & 18 & $1,339,632$ & 476,958 & 0.36 & 11 \\
\hline & 19 & 937,840 & 559,776 & 0.60 & 3 \\
\hline & 20 & $2,073,976$ & $1,032,917$ & 0.50 & 4 \\
\hline & 21 & $5,650,731$ & $2,103,211$ & 0.37 & 8 \\
\hline & 22 & $2,537,623$ & 365,547 & 0.14 & 22 \\
\hline & 23 & $3,485,657$ & 523,133 & 0.15 & 21 \\
\hline & 24 & $2,102,811$ & 286,095 & 0.14 & 23 \\
\hline & 25 & $6,745,192$ & $2,519,266$ & 0.37 & 9 \\
\hline & 26 & $2,244,089$ & $1,587,572$ & 0.71 & 2 \\
\hline & 27 & $2,267,360$ & $1,967,998$ & 0.87 & 1 \\
\hline \multicolumn{2}{|l|}{ Total } & $98,179,343$ & $29,096,653$ & - & - \\
\hline
\end{tabular}

2) 비오톱지수(Biotope Index)

중랑천 유역권 내 비오톱지수가 가장 높게 도출된 곳은 중랑 천 하류에 위치하는 유역권 2번 지역으로 최종 비오톱지수가 0.60 으로 전체 유역권 중 1 순위를 차지하였다. 유역권 2 번의 하 천 내 비오톱지수는 0.77 , 하천을 제외한 유역권 전체 비오톱지 수가 0.43 이었다. 유역권 2 번은 하천 내 비오톱 1 등급에 해당하 는 피도 $75 \%$ 이상 습지자생식물인 갈대, 물억새 등 초본이 우 점하였고, 하천 제방에는 버드나무가 분포하였기 때문에 하천 비오톱지수가 높게 도출되었다. 하천을 제외한 유역권 전체 면 적의 등급을 비교하였을 때, 비오톱지수는 0.43 으로 낮은 값을 보였는데, 이는 유역권 내 5 등급에 해당하는 시가화지역이 대 단위로 분포하였고, 응봉산을 제외하면 산림 및 근린공원 등 녹지 및 오픈스페이스로 구분되는 비오톱 1 등급의 비율이 $8.8 \%$ 로 등급 비율이 낮았기 때문이었다. 따라서 유역권 2 번지
역에 보전지역 설정 시 핵심보전지역인 하천을 중심으로 보전 강도를 구분하여 유역권을 관리하는 방안이 필요하다 판단되 었다.

두 번째는 중랑천 상류의 유역권 27번으로 최종 비오톱지수 가 0.60 으로 전체 유역권 중 2순위이었다. 유역권 27번의 하천 내 비오톱지수는 0.84 , 하천을 제외한 유역권 전체 비오톱지수 가 0.36 이었다. 유역권 27 번은 하천 내 비오톱 1 등급에 해당하 는 갈대, 물억새가 다수 분포하는 곳으로 하천 주변으로 버드 나무 등 습지성 자생식물이 다수 분포하고 있었다. 하천을 제 외한 유역권 전체 면적의 등급을 비교하였을 때, 비오톱지수는 0.36 으로 비교적 낮은 값을 보였는데, 유역권 27번 지역은 의정 부와 서울시의 경계로 하천 주변으로 대단위 주거시설, 도봉역, 경작지, 도봉산 광역환승센터 주차장 등 비오톱 3,5 등급에 해당 되는 시가화지역의 비율이 $38.8 \%$ 로 다소 높았다. 그러나 유역권 내 도봉산, 수락산 등 산림과 서울창포원 내 녹지 등 비오톱 1,2 등급의 비율이 $41.2 \%$ 로 타 지역에 비해 월등히 높아 보전지역 설정 시 높은 우선순위를 가질 수 있는 것으로 판단되었다.

중랑천 유역권 내 비오톱지수가 가장 낮은 곳은 중랑천 중류 에 위치하는 유역권 9번으로 최종 비오톱지수가 0.25 로 전체 유역권 중 27순위를 차지하였다. 유역권 9 번의 하천 내 비오톱 지수는 0.10. 하천을 제외한 유역권 전체의 비오톱지수가 0.40 이었다. 유역권 9 번은 하천 내 귀화식물의 분포가 높았고, 하천 산책로 변에 체육공원이 위치하여 시설지 및 포장지의 비율이 높아 하천 내 비오톱지수가 낮게 도출되었다. 하천을 제외한 유역권 전체 면적의 등급을 비교하였을 때, 비오톱지수가 0.40 으로 비교적 낮게 도출되었는데, 이는 해당 유역권 내 비오톱 5 등급에 해당되는 대단위 주거시설, 상업지, 업무시설 등 시가화 지역의 비율이 $46.4 \%$ 로 높은 비율을 차지하였기 때문으로 판 단되었다. 따라서 보전지역 설정 시 우선순위 제외, 전이지역 설정 등 방안이 필요하였다.

중랑천 유역권 내 비오톱지수 현황을 분석한 결과, 중랑천 중류의 초안산, 영축산, 봉화산이 인접하는 유역권 8 번, 10 번, 11 번 등을 제외한 나머지 유역권의 비오톱지수가 낮게 도출되 었다. 이는 하천 주변으로 대단위 주거시설인 아파트, 상업시 설, 업무시설, 도로 및 포장지, 지하철 역 등 고밀도 시가화지역 이 유역권 전면적으로 분포하고, 녹지 및 오픈스페이스의 면적 이 적었기 때문으로 판단되었다. 반면에 중랑천 상류의 도봉산, 수락산 등 산림과 인접하는 유역권 25번, 26번, 27번과 중랑천 하류의 한강 합수부, 청계천 합수부 등 하천합수부와 인접하는 유역권 1번, 2 번, 4 번 등은 유역권 내 산림 및 공원 녹지가 인 접하거나, 하천 내 갈대, 물억새, 버드나무 등 습지성 자연식생 의 우점 및 분포면적이 넓어 비오톱지수가 높게 도출되었다. 따라서 중랑천 유역권의 상류와 하류는 산림생태계, 하천생태 계 등 다양한 생물이 서식할 수 있는 서식처로서의 역할을 할 수 있는 곳으로 보전지역 설정 시 각각의 유역권을 관리하는 
것보다는 인접하는 유역권을 통합하여 유역권 전체를 보전 및 관리하는 방안이 필요하였다(Table 2 참조).

\section{3. 생태적 특성을 고려한 보전지역 구분}

1) 시나리오 I

중랑천 시나리오I의 BLM 지수 조정방법은 연구방법에서 제시한 수치 중 지표의 보전가치를 $95 \%$ 로 설정하여 보전지역 범위를 설정하였다. 보전가치를 기준으로 하여 시나리오를 설 정하고, BLM을 적용한 결과, 핵심보전지역(core area), 완충지 역(buffer area), 전이지역(transition area) 등 3개의 보전지역 으로 구분되어 보전지역간 누락없이 3 개 지구가 모두 도출되는 $\mathrm{BLM}=10$ 에서 지역 각각 면적 합에 대한 외곽길이 비율이 0.004로 가장 짧았고, 유역권 간 연결성이 높은 것으로 분석되 었다. 따라서 보전지구의 개수, 유역권 전체의 보전길이 등을 고려한 결과, $\mathrm{BLM}$ 이 0.01 과 7.5 가 아닌 10 으로 설정되었고, 유

Table 2. Biotope index by Jungrangcheon watershed

\begin{tabular}{|c|c|c|c|c|c|}
\hline \multicolumn{2}{|c|}{ Watershed } & $\begin{array}{c}\text { Biotope index } \\
\text { (inside the river) }\end{array}$ & $\begin{array}{c}\text { Biotope index } \\
\text { (arround the river) }\end{array}$ & $\begin{array}{c}\text { Biotope } \\
\text { index (total) }\end{array}$ & Priority \\
\hline \multirow{27}{*}{$\begin{array}{l}\text { Jungrang } \\
\text { Cheon } \\
\text { Stream }\end{array}$} & 1 & 0.60 & 0.35 & 0.48 & 6 \\
\hline & 2 & 0.77 & 0.43 & 0.60 & 1 \\
\hline & 3 & 0.38 & 0.44 & 0.41 & 15 \\
\hline & 4 & 0.50 & 0.45 & 0.48 & 7 \\
\hline & 5 & 0.58 & 0.32 & 0.45 & 10 \\
\hline & 6 & 0.48 & 0.32 & 0.40 & 16 \\
\hline & 7 & 0.42 & 0.36 & 0.39 & 17 \\
\hline & 8 & 0.59 & 0.37 & 0.48 & 5 \\
\hline & 9 & 0.10 & 0.40 & 0.25 & 27 \\
\hline & 10 & 0.27 & 0.35 & 0.31 & 23 \\
\hline & 11 & 0.53 & 0.41 & 0.47 & 8 \\
\hline & 12 & 0.44 & 0.40 & 0.42 & 12 \\
\hline & 13 & 0.51 & 0.43 & 0.47 & 9 \\
\hline & 14 & 0.42 & 0.42 & 0.42 & 14 \\
\hline & 15 & 0.27 & 0.41 & 0.34 & 22 \\
\hline & 16 & 0.12 & 0.42 & 0.27 & 26 \\
\hline & 17 & 0.32 & 0.42 & 0.37 & 19 \\
\hline & 18 & 0.22 & 0.38 & 0.30 & 24 \\
\hline & 19 & 0.20 & 0.36 & 0.28 & 25 \\
\hline & 20 & 0.28 & 0.48 & 0.38 & 18 \\
\hline & 21 & 0.30 & 0.40 & 0.35 & 21 \\
\hline & 22 & 0.22 & 0.50 & 0.36 & 20 \\
\hline & 23 & 0.45 & 0.39 & 0.42 & 13 \\
\hline & 24 & 0.36 & 0.53 & 0.45 & 11 \\
\hline & 25 & 0.53 & 0.47 & 0.50 & 3 \\
\hline & 26 & 0.65 & 0.35 & 0.50 & 4 \\
\hline & 27 & 0.84 & 0.36 & 0.60 & 2 \\
\hline
\end{tabular}

역권 별 외곽 경계의 길이 보정을 위해 지수 값에 10,000 을 곱 하여 값을 환산하였다.

설정된 $\mathrm{BLM}$ 을 10 으로 설정한 후 반복횟수에 따른 가장 효 율적인 목적기능값을 확인하기 위해 수치보정을 실시하였다. 초기설정값인 $1,000,000$ 회부터 시작하여 500,000 회, 100,000 회, 50,000 회, 10,000 회, 5,000 회, 1,000 회까지 반복하여 분석하였고, 담금질 기법의 알고리즘 중 0 까지 감소하는 수치는 초기 설정 값과의 비율을 고려하여 $10,000,5,000,1,000,500,100,50,10$ 등으로 설정하였다. 수치보정 결과, 반복횟수 1,000 회에 수치감 소 단위 10 에서 목적기능값(score)가 낮았으며, 가장 효율적인 수치로 판단되었다.

마지막 보정단계인 Zoneboundcost는 기존의 설정된 BLM과 반복횟수, $\mathrm{FPF}$ 값을 고정한 후 핵심보전지역(core area), 완충 지역(buffer area), 전이지역(transition area)간의 연결 수치를 0.00001 로 설정하고, 10 단위씩 수치를 늘려가면서 지역간의 연 결성에 대한 분석을 실시하였다. 보전지역이 충분히 확보되었 는지를 최우선 기준으로 선택하였으며, 각 지역간 그룹화 정도 를 판단하여 최종안을 선정하였다.

민감도분석을 통한 수치보정 및 반복횟수를 통한 수치보정, Zoneboundcost 수치보정 등 오차수정을 위한 작업한 결과, $\mathrm{CM}=0.00001$ 부터 $\mathrm{CM}=1$ 까지 총 6 개의 시나리오를 도출하였 다. 도출된 시나리오는 최종 시나리오 선정 기준에 따라 재분 류를 실시하였으며, 핵심보전지역의 유역권 수, 면적 등이 가장 넓게 형성된 시나리오, 핵심보전지역이 분산되어 있지 않고 하 나의 유역권을 형성하는 시나리오, 생태경관보전지역, 야생생 물보호구역 등 중요 보전지역가 포함되는 시나리오, 야생조류, 양서 - 파충류 등 동물이 다수 서식하는 유역권 등 총 4단계의 과정을 통해 시나리오를 검증하였다.

먼저 1 단계인 핵심보전지역의 유역권 수, 면적이 넓게 형성 된 시나리오는 $\mathrm{CM}=0.001, \mathrm{CM}=1$ 2개의 시나리오이었다. 시 나리오 $\mathrm{CM}=0.001$ 은 핵심보전지역의 수가 4 개, 비율은 0.27 로 나타났고, $\mathrm{CM}=1$ 은 핵심보전지역 유역권 수 가 7 개, 비율은 0.24 로 도출되었다. 2단계인 핵심보전지역이 분산되어 있지 않 고 하나의 유역권을 형성하는 시나리오는 시나리오 $\mathrm{CM}=0.1$, $\mathrm{CM}=1$ 2개가 선정되었다. $\mathrm{CM}=0.1$ 은 중랑천 상류의 유역권 2 개가 통합되어 하나의 유역권을 형성하고, 하류에는 유역권 1 개소가 도출되었다. $\mathrm{CM}=1$ 은 중랑천 상류의 5 개 유역권이 통 합되어 핵심보전지역으로 설정되었으며, 하류의 2개 유역권이 통합되어 핵심보전지역으로 지정되었다. 3단계인 생태경관보 전지역, 야생생물보호구역 등 중요 보전지역이 포함된 시나리 오는 $\mathrm{CM}=0.001, \mathrm{CM}=0.01, \mathrm{CM}=13$ 개의 시나리오로 도출되 었다. 선정된 3 개의 시나리오는 모두 중랑천 상류 야생생물 보 호구역이 포함되었으나, $\mathrm{CM}=0.01$ 은 중랑천 하류 철새보호구 역이 포함되지 않았다. 4 단계인 야생조류, 양서 - 파충류 등 동 물이 다수 서식하는 유역권이 포함된 시나리오는 한강 합수부, 
청계천 합수부 등 하천생태계와 도봉산, 수락산 등 산림생태계 가 포함된 유형으로 다시 구분하였다. 하천생태계가 포함되는 시나리오는 $\mathrm{CM}=0.0001, \mathrm{CM}=1$ 등 2 개로 하천 내 주요 종이 가장 많이 도출된 시나리오를 선택하였다. 산림생태계가 포함 되는 시나리오는 $\mathrm{CM}=0.1, \mathrm{CM}=1$ 등 2 개로 산새류의 비율이 가장 넓게 분포하고 있었다.

각 단계를 거쳐 선정된 최종 시나리오인 $\mathrm{CM}=1$ 은 중랑천 상 - 하류가 핵심보전지역으로 설정된 시나리오로 상류는 중랑 천 수계 주변으로 도봉산, 수락산, 초안산 등 산림과 연계된 유 역권과 방학천 등 인근지역의 수계가 인접한 곳으로 생물종 보 호 및 생태계 간 연계를 위해서 보전지역 설정이 필요하였다. 또한 상류에는 유역권 내 멸종위기종 II급으로 지정된 표범장 지뱀의 서식처인 중랑천 야생생물보호구역이 위치하는 하고 있었고, 하류에는 청계천, 한강합수부와 인접하고, 중랑천 하류 철새보호구역이 위치하고 있었다. 따라서 다양한 시나리오 중 단계별 시나리오를 통해 최종 선정된 $\mathrm{CM}=1$ 을 중랑천 시나리 오I의 최종안으로 선정하였다(Table 3 , Figure 3 참조).

\section{2) 시나리오 II}

시나리오 II 의 민감도분석을 통한 수치보정 및 반복횟수를

Table 3. The result of Jungrangcheon scenario ।

\begin{tabular}{|c|c|c|}
\hline \multicolumn{2}{|r|}{ Scenario I } & Contents \\
\hline \multirow{2}{*}{1} & \multirow{2}{*}{$\begin{array}{l}\text { - Number of } \\
\text { watersheds in } \\
\text { core area } \\
\text { - Watershed area } \\
\text { ratio of core area }\end{array}$} & $\begin{array}{l}\cdot \mathrm{CM}=0.001 \\
\text { - Number of watersheds: } 4 \\
\text { - Watershed area ratio: } 0.27\end{array}$ \\
\hline & & $\begin{array}{l}\cdot \mathrm{CM}=1 \\
\text { - Number of watersheds: } 7 \\
\text { - Watershed area ratio: } 0.24\end{array}$ \\
\hline \multirow{2}{*}{2} & \multirow{2}{*}{$\begin{array}{l}\text { - Number of } \\
\text { watersheds close to } \\
\text { the core area }\end{array}$} & $\begin{array}{l}\cdot \mathrm{CM}=0.1 \\
\text { - Upstream watershed } 2 \\
\text { - Downstream watershed } 1\end{array}$ \\
\hline & & $\begin{array}{l}\cdot \mathrm{CM}=1 \\
\text { - Upstream watershed } 5 \\
\text { - Downstream watershed } 2\end{array}$ \\
\hline \multirow{3}{*}{3} & \multirow{3}{*}{$\begin{array}{l}\text { - Adjacent to the } \\
\text { conservation area }\end{array}$} & $\begin{array}{l}\cdot \mathrm{CM}=0.001 \\
\text { - Wildlife reserve(upstrean) } \\
\text { - Migratory bird sanctuary (downstream) }\end{array}$ \\
\hline & & $\begin{array}{l}\cdot \mathrm{CM}=0.01 \\
\text { - Wildlife reserve(upstrean) }\end{array}$ \\
\hline & & $\begin{array}{l}\cdot \mathrm{CM}=1 \\
\text { - Wildlife reserve(upstrean) } \\
\text { - Migratory bird sanctuary(downstream) }\end{array}$ \\
\hline \multirow[b]{2}{*}{4} & \multirow{2}{*}{$\begin{array}{l}\text { - Places with many } \\
\text { wild animals in the } \\
\text { watershed } \\
\text { (adjacent mountains } \\
\text { and rivers) }\end{array}$} & $\begin{array}{l}\cdot \mathrm{CM}=0.0001, \mathrm{CM}=0.001 \\
\text { - Hanriver, } \\
\text { Cheonggyecheon stream }\end{array}$ \\
\hline & & $\begin{array}{l}\text { - } \mathrm{CM}=0.1, \mathrm{CM}=1 \\
\text { - Mt. Dobogsan, Mt.Suraksan } \\
\text { - Mt. Choansan, Hanriver } \\
\text { - Cheonggyecheon, Banghakcheon stream }\end{array}$ \\
\hline
\end{tabular}

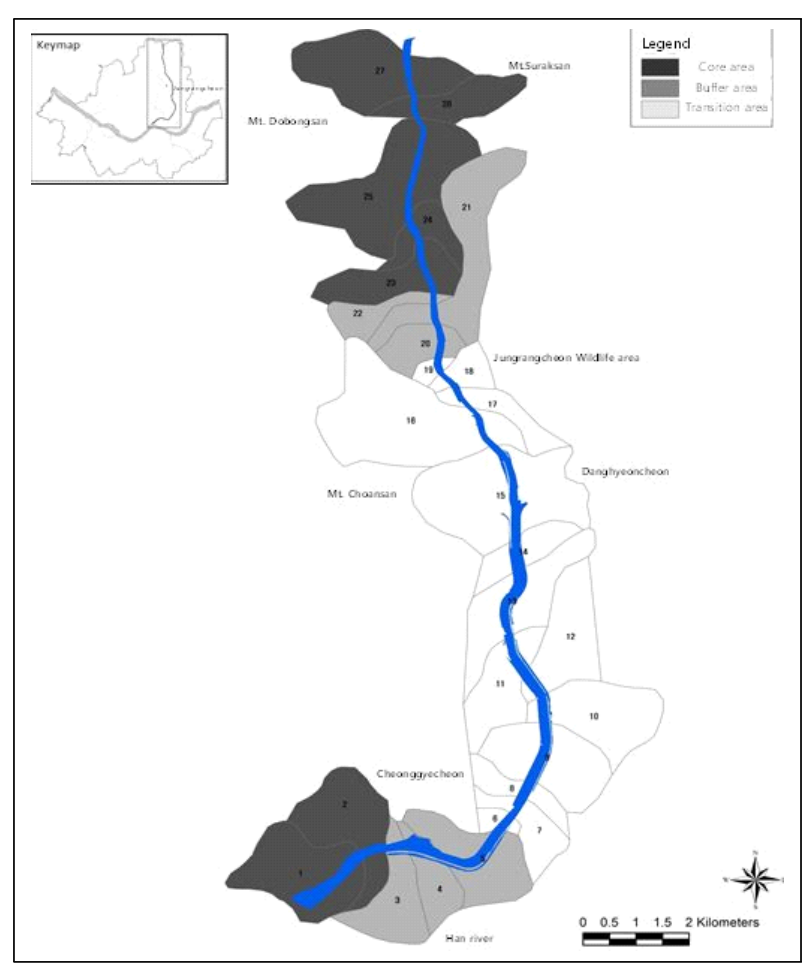

Figure 3. The result map of Jungrangcheon scenario । Legend: $\square$ Core area $\square$ Buffer area $\square$ Transition area

통한 수치보정, Zoneboundcost 수치보정 등 오차수정을 위한 작업한 결과, $\mathrm{CM}=0.00001$ 부터 $\mathrm{CM}=1$ 까지 총 6 개의 시나리오 를 도출하였다. 도출된 시나리오는 최종 시나리오 선정 기준에 따라 재분류를 실시하였으며, 핵심보전지역의 유역권 수, 면적 등이 가장 넓게 형성된 시나리오, 핵심보전지역이 분산되어 있 지 않고 하나의 유역권을 형성하는 시나리오, 생태경관보전지 역, 야생생물보호구역 등 중요 보전지역가 포함되는 시나리오, 야생조류, 양서 - 파충류 등 동물이 다수 서식하는 유역권 등 총 4단계의 과정을 통해 시나리오를 검증하였다.

먼저 1단계인 핵심보전지역의 유역권 수, 면적이 넓게 형성 된 시나리오는 $\mathrm{CM}=0.001, \mathrm{CM}=0.01$ 2개의 시나리오이었다. 시나리오 $\mathrm{CM}=0.001$ 은 핵심보전지역의 수가 5 개, 비율은 0.18 로 나타났고, $\mathrm{CM}=0.01$ 은 핵심보전지역 유역권 수가 5 개, 비율 은 0.24 로 도출되었다. 2 단계인 핵심보전지역이 분산되어 있지 않고, 하나의 유역권을 형성하는 시나리오는 시나리오 $\mathrm{CM}=$ $0.0001, \mathrm{CM}=0.001, \mathrm{CM}=0.1, \mathrm{CM}=1$ 등 총 4 개가 선정되었다. $\mathrm{CM}=0.0001$ 은 중랑천 상류의 유역권이 2개, 하류의 유역권 2 개가 보전지역으로 설정되었고, $\mathrm{CM}=0.001$ 은 중랑천 상류가 3 개, 하류가 2 개로 설정되었다. $\mathrm{CM}=0.1$ 은 중랑천 상류 유역권 2 개, 중류에 1 개, 하류에는 2 개가 설정되어 있었다. $\mathrm{CM}=1$ 은 중랑천 중류에 2 개, 하류에 1 개가 형성되어 있었다. 3 단계인 생 태경관보전지역, 야생생물보호구역 등 중요 보전지역이 포함된 시나리오는 $\mathrm{CM}=0.0001, \mathrm{CM}=0.001, \mathrm{CM}=0.1$ 등 3 개의 시나 
리오로 도출되었다. 선정된 3개의 시나리오는 모두 중랑천 상 류 야생생물 보호구역, 중랑천 하류 철새보호구역이 포함되어 보전지역 설정이 적절하다 판단되었다. 4 단계인 야생조류, 양 서·파충류 등 동물이 다수 서식하는 유역권이 포함된 시나리오 는 한강 합수부, 청계천 합수부 등 하천생태계와 도봉산, 수락 산 등 산림생태계가 포함된 유형으로 다시 구분하였다. 먼저 하천생태계가 포함되는 시나리오는 6 개 모두 동일하게 포함되 었다. 그러나 중랑천 상류의 도봉산, 수락산 등 산림과 인접하 는 유역권이 포함된 시나리오는 $\mathrm{CM}=0.001$ 등 1 개 시나리오로 유일하였다.

각 단계를 거쳐 선정된 중랑천 시나리오피의 최종안인 $\mathrm{CM}=0.001$ 은 중랑천 상 - 하류가 핵심보전지역으로 설정된 시

Table 4. The result of Jungrangcheon Scenario II

\begin{tabular}{|c|c|c|}
\hline & Scenario II & Contents \\
\hline \multirow{2}{*}{1} & \multirow{2}{*}{$\begin{array}{l}\text { - Number of } \\
\text { watersheds in } \\
\text { core area } \\
\text { - Watershed area } \\
\text { ratio of core area }\end{array}$} & $\begin{array}{l}\cdot \mathrm{CM}=0.001 \\
\text { - Number of watersheds: } 5 \\
\text { - Watershed area ratio: } 0.18\end{array}$ \\
\hline & & $\begin{array}{l}\mathrm{CM}=1 \\
\text { - Number of watersheds: } 5 \\
\text { - Watershed area ratio: } 0.24\end{array}$ \\
\hline \multirow{4}{*}{2} & \multirow{4}{*}{$\begin{array}{l}\text { - Number of } \\
\text { watersheds close to } \\
\text { the core area }\end{array}$} & $\begin{array}{l}\cdot \mathrm{CM}=0.0001 \\
\text { - Upstream watershed } 2 \\
\text { - Downstream watershed } 2\end{array}$ \\
\hline & & $\begin{array}{l}\cdot \mathrm{CM}=0.001 \\
\text { - Upstream watershed } 3 \\
\text { - Downstream watershed } 2\end{array}$ \\
\hline & & $\begin{array}{l}\text { - CM }=0.1 \\
\text { - Upstream watershed } 5 \\
\text { - Midstream watershed } 1 \\
\text { - Downstream watershed } 2\end{array}$ \\
\hline & & $\begin{array}{l}\cdot \mathrm{CM}=1 \\
\text { - Midstream watershed } 2 \\
\text { - Downstream watershed } 1\end{array}$ \\
\hline \multirow{3}{*}{3} & \multirow{3}{*}{$\begin{array}{l}\text { - Adjacent to the } \\
\text { conservation area }\end{array}$} & $\begin{array}{l}\cdot \mathrm{CM}=0.001 \\
\text { - Wildlife reserve(upstrean) } \\
\text { - Migratory bird } \\
\text { Sanctuary(downstream) }\end{array}$ \\
\hline & & $\begin{array}{l}\mathrm{CM}=0.001 \\
\text { - Wildlife reserve(upstrean) } \\
\text { - Migratory bird } \\
\text { Sanctuary(downstream) }\end{array}$ \\
\hline & & $\begin{array}{l}\cdot \mathrm{CM}=0.1 \\
\text { - Wildlife reserve(upstrean) } \\
\text { - Migratory bird } \\
\text { Sanctuary(downstream) }\end{array}$ \\
\hline \multirow[t]{2}{*}{4} & \multirow{2}{*}{$\begin{array}{l}\text { Places with many } \\
\text { wild animals in the } \\
\text { watershed } \\
\text { (adjacent mountains } \\
\text { and rivers) }\end{array}$} & $\begin{array}{l}\text { - } \mathrm{CM}=0.1, \mathrm{CM}=1 \\
\text { - Mt. Dobogsan, Mt.Suraksan } \\
\text { - Mt. Choansan, Hanriver } \\
\text { - Cheonggyecheon Stream } \\
\text { Banghakcheon Stream }\end{array}$ \\
\hline & & $\begin{array}{l}\cdot \mathrm{CM}=0.001,0.01 \\
\text { - Mt. Dobogsan, Mt.Suraksan }\end{array}$ \\
\hline
\end{tabular}

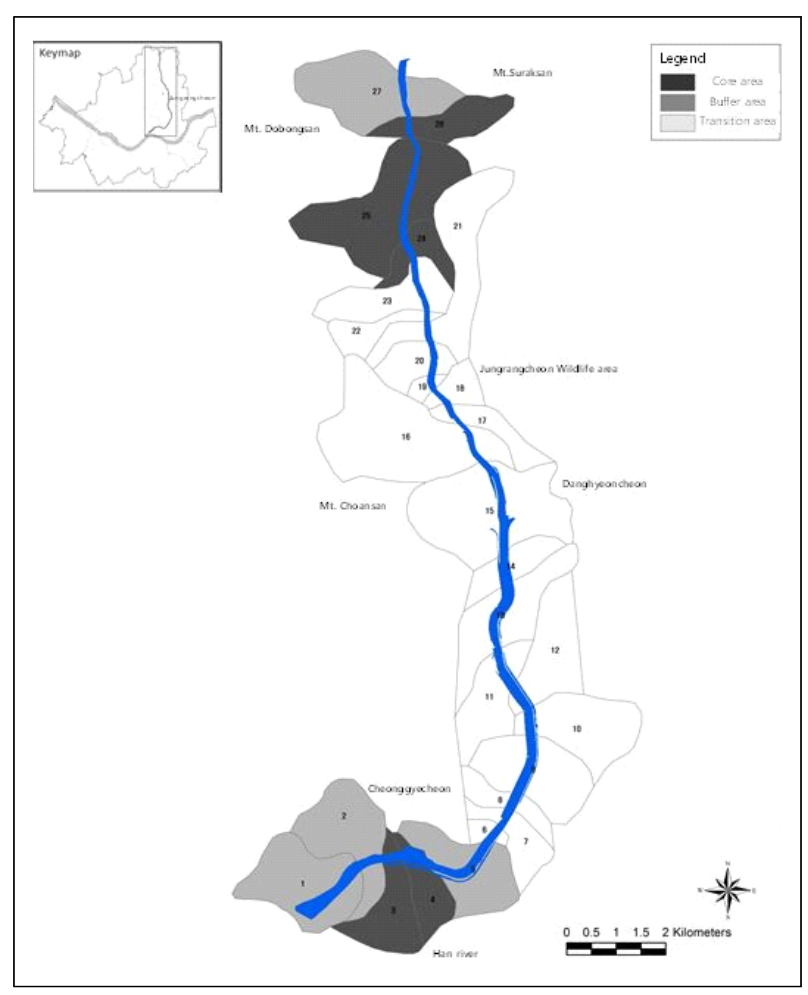

Figure 4. The result map of Jungrangcheon scenario II Legend: $\square$ Core area $\square$ Buffer area $\square$ Transition area

나리오로 상류는 중랑천 수계 주변으로 도봉산, 수락산, 초안산 등 산림과 연계된 유역권과 방학천 등 인근지역의 수계가 인접 한 곳으로 생물종 보호 및 생태계 간 연계를 위해서 보전지역 설정이 필요하였다. 또한 상류에는 유역권 내 멸종위기종 II 급 으로 지정된 표범장지뱀의 서식처인 중랑천 야생생물보호구역 이 위치하고 있었고, 하류에는 청계천, 한강합수부와 인접하고, 중랑천 하류 철새보호구역이 위치하고 있었다. 따라서 다양한 시나리오 중 단계별 시나리오를 통해 최종 선정된 $\mathrm{CM}=0.001$ 을 중랑천 시나리오 II 의 최종안으로 선정하였다(Table 4, Figure 4 참조).

\section{3) 최종안 선정}

시나리오 I, II 등 보전가치를 기준으로 도출된 시나리오 별 최종안을 비교한 결과, 다음과 같은 결과를 도출하였다. 보전가 치를 $90 \%$ 를 부여한 시나리오 I 의 핵심보전지역 유역권 수는 7 개, 면적은 $13,888,261 \mathrm{~m}^{2}$ 로 전체 유역권 중 $24 \%$ 가 도출되었 다. 핵심보전지역의 보전가치를 $70 \%$ 를 부여하여 보전지역 간 연계를 높인 시나리오II 의 핵심보전지역은 6 개로 면적은 $10,349,511 \mathrm{~m}^{2}$ 로 전체 유역권 중 $18 \%$ 를 차지하였으며, 시나리오 I 과 II의 핵심보전지역은 모두 중랑천 상류와 하류에 위치하 고 있었다. 시나리오 I 과 시나리오 II 의 핵심보전지역을 비교한 결과, 시나리오 I 의 핵심보전지역 유역권 수와 면적 모두 높게 도출되었다. 
핵심보전지역에 인접한 완충지역을 비교한 결과, 시나리오 $\mathrm{I}$ 은 6 개의 유역권으로 면적은 $7,801,651 \mathrm{~m}^{2}$ 를 차지하였으며, 전 체 유역권 중 $13 \%$ 가 도출되었다. 시나리오프는 4 개의 유역권 으로 면적은 $11,925,086 \mathrm{~m}^{2}$ 를 차지하였으며, 전체 유역권 중 $20 \%$ 가 도출되었다. 중랑천 유역권 내 완충지역 수는 시나리오 I 이 6개, 시나리오II가 4 개로 시나리오 I 이 많았으나, 면적비 율은 시나리오 II 가 $20 \%$ 로 월등히 높았다. 이는 시나리오 I 에 서 핵심보전지역으로 설정된 유역권이 시나리오 II 에서 완충지 역으로 설정되어 유역권 수는 적었으나 면적의 차이가 발생한 것이었다.

시나리오 별 핵심보전지역 결합 여부를 파악한 결과, 시나리 오I이 중랑천 상류에 5 개 유역권, 하류에 2개 유역권이 연계 되어 형성되어 있었고, 시나리옾ㄴ는 중랑천 상류에 3개 유역 권, 하류에 2 개 유역권이 연계되어 있었다. 핵심보전지역 내 중 랑천 상류 야생생물 보호구역, 중랑천 하류 철새보호구역 등 주 요 보전지역은 시나리오 I, II 모두 유역권 내부에 포함되고

Table 5. The comparison result of Jungrangcheon scenario I and II

\begin{tabular}{|c|c|c|c|c|}
\hline \multicolumn{3}{|c|}{ Type } & Scenario I & Scenario II \\
\hline \multirow{5}{*}{$\begin{array}{l}\text { Core } \\
\text { area }\end{array}$} & \multicolumn{2}{|c|}{ Conservation value } & $90 \%$ & $70 \%$ \\
\hline & \multicolumn{2}{|c|}{$\begin{array}{l}\text { Number of } \\
\text { watersheds }\end{array}$} & 7 & 5 \\
\hline & \multicolumn{2}{|c|}{$\operatorname{Area}\left(\mathrm{m}^{2}\right)$} & $13,888,261 \mathrm{~m}^{2}$ & $10,349,511 \mathrm{~m}^{2}$ \\
\hline & \multicolumn{2}{|c|}{ Area ratio $(\%)$} & 0.24 & 0.18 \\
\hline & \multicolumn{2}{|c|}{$\begin{array}{l}\text { Core area } \\
\text { conservation target }\end{array}$} & $\begin{array}{l}\text { Upstream, } \\
\text { downstream }\end{array}$ & $\begin{array}{c}\text { Upstream, } \\
\text { downstream }\end{array}$ \\
\hline \multirow{3}{*}{$\begin{array}{l}\text { Buffer } \\
\text { area }\end{array}$} & \multicolumn{2}{|c|}{$\begin{array}{l}\text { Number of } \\
\text { watersheds }\end{array}$} & 6 & 4 \\
\hline & \multicolumn{2}{|c|}{$\operatorname{Area}\left(\mathrm{m}^{2}\right)$} & $7,801,651 \mathrm{~m}^{2}$ & $11,925,086 \mathrm{~m}^{2}$ \\
\hline & \multicolumn{2}{|c|}{ Area ratio $(\%)$} & 0.13 & 0.20 \\
\hline \multicolumn{3}{|c|}{$\begin{array}{l}\text { Number of watersheds } \\
\text { connected between } \\
\text { protected areas }\end{array}$} & $\begin{array}{r}\text { - Upstream } \\
\text { watershed } 5 \\
\text { - Downstream } \\
\text { watershed } 2\end{array}$ & $\begin{array}{l}\text { - Upstream } \\
\text { watershed } 3 \\
\text { - Downstream } \\
\text { watershed } 2\end{array}$ \\
\hline \multicolumn{3}{|c|}{$\begin{array}{l}\text { Number of watersheds } \\
\text { adjacent to the } \\
\text { protected area }\end{array}$} & $\begin{array}{l}\text { - Wildlife reserve } \\
\text { (upstrean) } \\
\text { - Migratory bird } \\
\text { sanctuary } \\
\text { (downstream) }\end{array}$ & $\begin{array}{l}\text { - Wildlife reserve } \\
\text { (upstrean) } \\
\text { - Migratory bird } \\
\text { sanctuary } \\
\text { (downstream) }\end{array}$ \\
\hline \multirow{2}{*}{\multicolumn{2}{|c|}{$\begin{array}{l}\text { Wildlife } \\
\text { habitat status }\end{array}$}} & Bird & $\begin{array}{l}\text { Aix galericulata, } \\
\text { Charadrius placidus }\end{array}$ & $\begin{array}{l}\text { Aix galericulata, } \\
\text { Charadrius placidus }\end{array}$ \\
\hline & & $\begin{array}{l}\text { Amphibia } \\
\text { reptile }\end{array}$ & $\begin{array}{l}\text { Mongolia } \\
\text { racerunner }\end{array}$ & $\begin{array}{l}\text { Mongolia } \\
\text { racerunner }\end{array}$ \\
\hline \multicolumn{3}{|c|}{ Watershed adjacent to forest } & \begin{tabular}{|l|} 
- Upstream \\
Mt. Dobong, Surak \\
- Downstream \\
Uengbong
\end{tabular} & $\begin{array}{l}\text { - Upstream } \\
\text { Mt. Surak } \\
\text { - Downstream } \\
\text { Uengbong }\end{array}$ \\
\hline \multicolumn{3}{|c|}{ Link to other rivers } & $\begin{array}{l}\text { - Han river } \\
\text { - Cheonggyecheon } \\
\text { - Dobongcheon } \\
\text { - Banghakcheon }\end{array}$ & $\begin{array}{l}\text { - Han river } \\
\text { - Cheonggyecheon }\end{array}$ \\
\hline
\end{tabular}

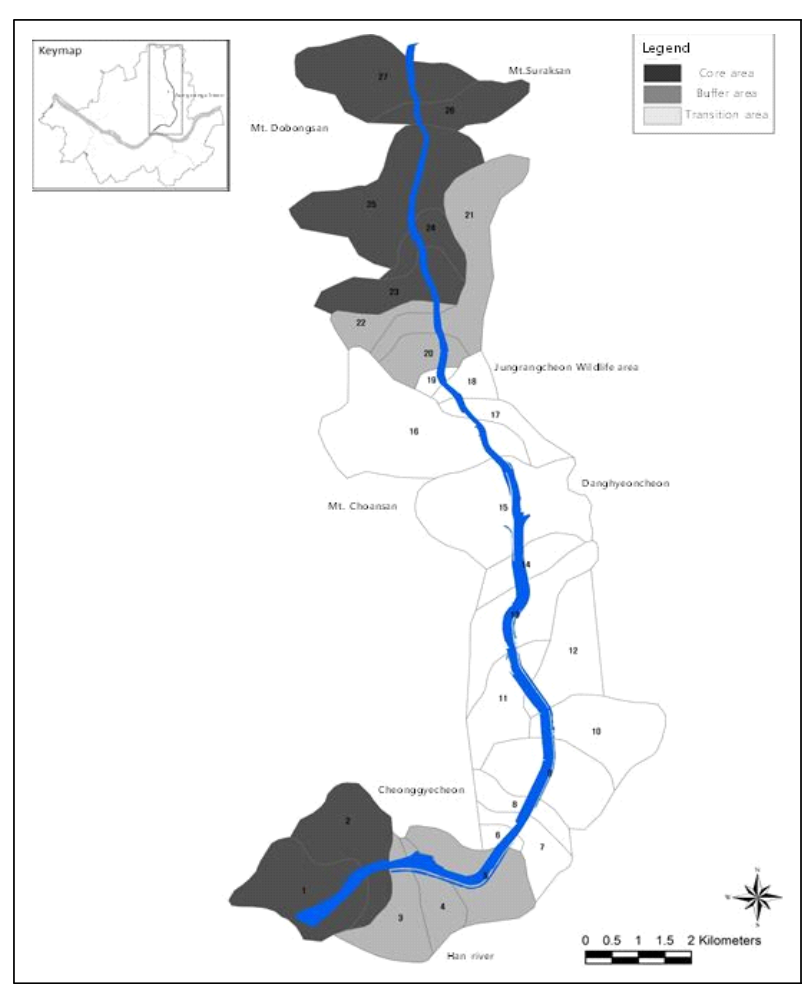

Figure 5. The final conservation area map of Jungrangcheon Legend: Core area $\square$ Buffer area $\square$ Transition area

있었으며, 보전지역 내 서식하는 표범장지뱀, 원앙, 흰목물떼새 등 멸종위기종, 천연기념물 등은 모두 동일하게 분포하였다.

중랑천 시나리오 I 과 II를 비교한 결과, 중랑천 시나리오 I 이 최종안으로 적합하였다. 시나리오 I 의 핵심보전지역은 도봉 산, 수락산, 응봉산 등 산림생태계와 한강합수부, 청계천 합수 부, 도봉 1,2 천 합수부, 방학천 합수부 등 하천생태계 등 생물 의 서식과 은신처로 적합하고, 생물이 이동할 수 있는 이동통 로 역할을 충분히 수행하는 곳으로 보전지역 설정 시 생물다양 성 증진에 큰 도움을 줄 수 있었다. 또한 중랑천 상류 유역권 전체가 보전지역으로 설정되어 기존의 중랑천 상류 야생생물 보호구역의 서식범위가 확장 등이 가능하므로 시나리오I이 적합하였다(Table 5, Figure 5 참조).

\section{4. 보전지역 검증과 관리방안}

중랑천의 핵심보전지역은 Marxan with zones 프로그램을 이용 하여 대상지의 분석기준을 설정한 후 프로그램 내 변수에 따라 반 복작업을 실행하여 최적안을 도출해주는 담글질기법(annealing algorithm)을 이용하여 보전지역 최종안을 도출하였다. 생물의 이동범위를 고려하여 서식범위인 유역권을 설정하였고, 기존 보전지역으로 지정된 하천 내부뿐만 아니라, 유역권 전체로 확 장하여 분석을 실시하였다. 분석방법은 중랑천 수계 주변으로 방학천, 우이천, 묵동천, 청계천 등 하천 생태계, 도봉산, 수락 
산, 초안산, 영축산, 불암산 등 산림생태계, 서울숲 등 도심 내 공원녹지 등 녹지 및 오픈스페이스의 유무, 서울시 도시생태현 황도를 통해 작성된 유역권 전체의 불투수포장비율, 현장조사 로 작성된 하천 내 비오톱유형도와 하천을 제외한 유역권 전체 의 비오톱유형, 유역권 내 동물생태 출현현황 등의 자료를 토 대로 분석을 실시하였다.

중랑천의 핵심보전지역은 중랑천 상류 야생생물보호구역과 하류의 철새보호구역 등 현재 지정된 2개의 보호구역이었다. 중랑천 상류 야생생물 보호구역은 녹천교 상계교 구간에 위 치하며, 멸종위기종 II급으로 지정된 표범장지뱀이 서식하는 공간이었다. 하천둔치와 수면사이의 모래톱 등이 보전지역으로 설정되어 있으나, 현재의 보호구역은 보호종이 출현한 지점을 기준으로 일정범위를 고려하여 보전지역을 설정하고 있으므로, 생물의 이동범위 및 주변 환경에 따른 서식범위를 고려하지 않 아 보전지역 설정에 오류가 있었다. 또한 보전지역 내 산책로, 자전거도로 등 하천 이용자를 위해 조성된 시설 등으로 로드킬 등 생물에게 위협이 되는 요인들이 많아 생물 서식이 어려운 환경이었다.

중랑천 하류 철새보호구역은 중랑천과 한강 합수부 사이에 위치하며, 겨울철 철새 이동시기 중 일정기간 머무는 곳으로 다양한 철새를 서식하고 관찰할 수 있는 공간이었으며, 생물다 양성 증진을 위해서는 보전 및 관리방안이 필요하였다. 현재 보호구역은 하천 수면을 기준으로 보전지역이 설정되어 있는 데, 하천 수변 내 녹지, 응봉산 등이 포함되지 않아 보전지역 설정에 오류가 있었으며, 하천 내 어로행위 등 생물서식에 위 협이 되는 요인이 많았다.

현재 보전지역으로 설정된 중랑천 상류와 하류 보전지역에 대한 개선을 위해 하천 내부와 유역권 전체 관리방안을 제안하 였다. 먼저 하천 내 관리방안으로는 첫째, 불법 어로행위, 로드 킬 등 생물 위협요인 제거를 위한 산책로 및 자전거도로 우회 로 조성 및 산책로 폐쇄, 철새보호구역 내 어로행위 감시 등이 필요하였다. 둘째, 지속적인 모니터링을 통한 생물서식처 변화 기록 및 위협요인 조기 제거 등이 필요하였다. 보전지역 내 생 물 서식현황 및 변화를 기록하여 생물에 위협이 되는 요인을 제거할 필요가 있었다. 또한 하천 내 생태계 교란종으로 지정 된 단풍잎돼지풀, 미국쑥부쟁이 등 식생의 제거, 환삼덩굴, 가 시박 등 덩굴성 식물의 제거를 통해 식생 피압을 막아야 할 필 요가 있었다. 셋째, 생물의 번식기, 산란기 등 생물활동에 중요 한 은신처 및 서식처를 제공하기 위해 버드나무, 갈대, 물억새 등을 수변가에 조성하고, 서식처 주변을 통제하여 일시적으로 출입을 금지하는 방안이 필요하였다. 하천 내 이용자의 출입을 막아 생물의 안전한 생물활동을 유도할 필요가 있었다. 넷째, 하천 내 어도 조성을 통한 생물 먹이터 조성 등의 방안이 필요 하였다. 중랑천 하류 철새보호구역에는 어류를 먹이로 하는 야
생조류들이 다수 관찰되는 곳으로 하천 내 어도 조성을 통해 먹이를 공급해야 할 필요가 있었다.

유역권 전체의 관리방안으로는 첫째, 기존 보전지역과 인접 하는 산림과 하천생태계의 연계를 위해 하천과 산림 사이에 거 점녹지를 조성하여 생물 이동통로 설정 등 방안이 필요하였다, 이를 통해 하천 내 생물뿐만 아니라, 주변의 다양한 서식처에 서 이동이 가능하여 생물다양성 증진에 도움을 줄 수 있는 방 안이 필요하였다. 둘째, 보전지역 주변 안내센터 조성을 통한 도심 내 보전지역 홍보 및 시민참여 유도가 필요하였다. 중랑 천 내 보전지역으로 설정된 상류와 하류에는 보전지역 설정에 대한 안내가 부족하여 해당지역을 모르고 지나치는 경우가 많 아 로드킬, 낚시 등 불법어로행위 등이 발생되고 있었다. 따라 서 보전지역을 홍보하기 위해 유역권 내 안내센터를 조성하여 지역주민에게 생물보전지역에 대한 교육을 제공하여 인식변화, 자발적인 주민참여를 통한 하천 모니터링 등을 유도해야 할 필 요가 있었다.

\section{IV. 결론}

본 연구는 Marxan with zone 프로그램을 적용하여 서울시 내 도시하천 중 중랑천을 대상으로 생태계 가치를 고려한 보전 지역 설정을 목적으로 하였다. 첫째, 보전지역 설정 프로그램 중 하나인 Marxan with zones는 생태계 가치에 따른 맵핑지표 를 통해 유형 별 도면을 작성하고, 유형 별 도면을 중첩시킨 후 보전지역의 길이 및 다양한 변수에 따라 반복적인 작업을 통해 최적의 시나리오를 작성하고, 최적의 시나리오를 이해관계자들 에게 제공해준다. 따라서 하천의 구조 유형이 비슷한 국내 하 천을 구분하여 선정된 하천을 분석하여 도출된 최종안을 기준 으로 국내 대부분의 하천에 적용 가능하였다.

둘째, Marxan 프로그램을 이용한 보전지역 설정을 위해서는 생태계 가치를 고려하여 작성된 기초자료가 필요하였다. 보전 지역의 계획단위는 산림분포비율이 높은 한국의 지형특성을 반영하고, 도심지 내부를 흐르는 하천 및 주변 수계, 야생동물 서식단위의 기본단위 등을 고려한 유역권 설정이 필요하였다. 기존 설정된 보전지역은 수면과 하천 내부만 설정되었고, 생물 의 이동범위 및 서식범위, 주변 서식환경 등을 고려하지 않은 경계설정으로 보전지역 설정에 오류가 있었다. 따라서 유역권 을 통한 보전범위 설정 시 대상지의 경사, 하천 및 수계, 중형 포유류의 핵심행동권 범위 등을 고려한 보전지역 설정이 필요 하였다.

셋째, 하천의 생태적 가치를 고려한 맵핑지표 설정이 필요하 였다. 서울시 도시생태현황도에서 도출한 불투수포장율을 기준 으로 작성된 불투수지수, 서울시 도시생태현황도에서 하천을 제외한 유역권 전체의 토지이용유형과 식생현황을 기준으로 
작성된 비오톱지도, 현장조사를 통해 하천 내부의 식생유형을 기준으로 작성된 하천 내 비오톱지도, 야생조류 및 양서 - 파충 류 출현지점 및 현황을 통해 작성된 동물생태 출현현황도 등 다양한 유형의 맵핑지표가 작성되어 Marxan with zones 프로 그램에 반영되었다.

넷째, 기존 생태경관보전지역의 검증 및 야생생물보호구역 설정체계를 검증한 결과, 경계설정 및 보전지역 설정에 대한 기준은 있었으나, 생물이 출현한 지점을 중심으로 보전경계가 지정되어 있으므로, 생물의 이동범위, 서식처 확대 및 주변지역 연계를 고려하지 않은 경계설정으로 오류가 있었다. 따라서 기 존 보전지역의 생물서식범위 확대, 주변 생물권의 연계를 고려 한 보전지역 설정이 필요하였다.

관리방안은 하천과 유역권을 구분하여 제안하였다. 하천에서 는 보호지역 내에서 발생하는 불법행위, 생태계 교란야생생물 의 관리와 주요 보호야생동물의 서식지 보호관리, 이용자 관리 등을 제안하였고, 유역권 차원에서는 하천과 주변 생태계와의 연결성 강화, 하천 이용자들에 대한 인식제고를 위한 홍보 및 주민참여 모니터링 등을 제안하였다.

본 연구는 하천 생태계의 지속가능한 관리를 위한 관리지역 설정에 있어 하천을 포함하는 유역권을 공간기준으로 설정하 고, 하천의 생태적 가치와 주변 유역권의 생태적 가치를 종합 하여 정량적인 분석방법을 활용하였다. 특히 도시에서 하천의 생태적 기능과 유역권의 제내지가 하천에 미치는 영향 등을 고 려했을 때 하천의 보호지역을 포함한 관리지역의 설정은 하천 구역 내로 제안되는 것이 아니라, 보다 광역적인 측면에서 유 역권 차원에서 시행되어야 하며, 유역권의 관리 또한 도시의 전체적인 생물다양성 관리 측면에서 도시계획 등과 연계되어 시행이 필요하였다.

\section{References}

1. Ardron, J. A., H. P. Possingham and C. J. Klein(2010) Marxan Good Practices Handbook, Version 2. Pachific Marine Analysis and Research Association, Victoria, BC, Canada. p. 165.

2. Bos, J.(1993) Zoning in forest management-a quadratic assignment problem solved by simulated annealing. Journal of Environmental Management 37(2): 127-145.

3. Choi, S. H.(2008) Biotope mapping and evaluation in Gangseo-gu of Busan metropolian city. Journal of the Korean Association of $\mathrm{Geo}^{-}$ graphic Information Studies 11(3): 92-106.

4. Horton, R. E.(1945) Erosional development of streams and their drainage basins: Hydro-physical approach to quantitative morphology, Geological Society of America Bulletin 56(3): 275-370.

5. Jung, T. J.(2010) A Study on the Construction Methods and the Distribution of Proper Spatial Function for Making Urban Stream into Close-to-Nature Stream. Marster's Thesis, University of Seoul. Korea. p. 143.

6. Lee, H. J., J. Y. Cha, C. U. Chung, Y. C. Kim, S. C. Kim, G. H. Kwon and J. J. Kim(2014) Home range analysis of tree midium-sized mammals in Sobeaksan National Park a water system. Jornal of the Korea Society for Environmental Restoration Technology 17(6) : 51-60.

7. Otto, B., K. McCormick and M. Leccese(2004) Ecological Riverfront Design: Restoring Rivers, Connecting Communities. American Planning Association. p. 151.

8. Seoul(2017) Seoul River Environment Evaluation and Management Strategy Establishment. Seoul Metropolitan Government. p. 1,045.

9. Straher, A. N.(1952) Hypsometric of erosional topography. Bulletin Geol. Soc. Amer 63: 1,117-1,142.

10. Seoul Independent City(2003) Maintenance Plan for River in Cheongyecheon Stream. Seoul Independent City. p. 427.

11. Watts, M., B. Ian, S. Romola, K. Carissa, W. Kerrie, S. Charles, L. Reinaldo, K. Lindsay and P. Hugh(2009) Marxan with zones: Software for optimal conservation based land-and sea-use zoning. Environmental Modelling \& Software 24: 1513-1521.

12. Woo, H. S.(2004) Evolution and prospect of national river project-indicators of Cheonggyecheon project. Journal of Korea Water Resources Association 37(1): 41-46.

13. Yoon, H. G.(2018) A Study on Zoning and Management of Conservation Area and Ecological Management Plan on Urban Stream Using Marxan. Master's Thesis. Graduate School of University of Seoul, Korea. p. 212.

\begin{aligned} \hline Received : 28 July, 2020 \\ Revised : 31 August, 2020 \\ Accepted : 31 August, 2020 \\ 4인익명 심사필 \end{aligned}

(1st) 